\title{
Complications of radiofrequency coagulation of liver tumours
}

\author{
S. Mulier, P. Mulier*, Y. Ni†, Y. Miao \\ Department of General Surgery, University Hospital Mont-Godinne, Catholic University of Louvain, Belgium, *Biomedical engineer, Minneapolis, \\ Minnesota, USA, Departments of †Radiology and đ[Surgical Oncology, University Hospital Gasthuisberg, Catholic University of Leuven, Belgium, \\ $\ddagger$ Department of General Surgery, The First Affiliated Hospital of Nanjing Medical University, Nanjing, China and §Department of Radiology, \\ University Hospital of Nantes, Nantes, France \\ Correspondence to: Dr S. Mulier, Department of Surgery, University Hospital of Mont-Godinne, B-5530 Yvoir, Belgium \\ (e-mail: stefaan.mulier@mont.ucl.ac.be)
}

\begin{abstract}
Background: Radiofrequency coagulation (RFC) is being promoted as a novel technique with a low morbidity rate in the treatment of liver tumours. The purpose of this study was to assess critically the complication rates of RFC in centres with both large and limited initial experience, and to establish causes and possible means of prevention and treatment.

Methods: This is an exhaustive review of the world literature (articles and abstracts) up to 31 December 2001; 82 independent reports of RFC of liver tumours were analysed.

Results: In total, 3670 patients were treated with percutaneous, laparoscopic or open RFC. The mortality rate was 0.5 per cent. Complications occurred in 8.9 per cent: abdominal bleeding in 1.6 per cent, abdominal infection in 1.1 per cent, biliary tract damage in 1.0 per cent, liver failure in 0.8 per cent, pulmonary complications in $\mathbf{0 . 8}$ per cent, dispersive pad skin burn in 0.6 per cent, hepatic vascular damage in 0.6 per cent, visceral damage in 0.5 per cent, cardiac complications in 0.4 per cent, myoglobinaemia or myoglobinuria in 0.2 per cent, renal failure in 0.1 per cent, tumour seeding in 0.2 per cent, coagulopathy in 0.2 per cent, and hormonal complications in 0.1 per cent. The complication rate was 7.2, 9.5, 9.9 and 31.8 per cent after a percutaneous, laparoscopic, simple open and combined open approach respectively. The mortality rate was $0.5,0,0$ and 4.5 per cent respectively.

Conclusion: The morbidity and mortality of RFC, while low, is higher than previously assumed. With adequate knowledge, many complications are preventable.
\end{abstract}

Paper accepted 17 April 2002

British Journal of Surgery 2002, 89, 1206-1222

\section{Introduction}

Radiofrequency coagulation (RFC) is one of several competing interstitial therapies that have recently been developed for the focal treatment of inoperable liver tumours. The purpose of this study was to assess the nature and the rate of complications, including mortality, of RFC of liver tumours from centres with both large and limited initial experience. It was also hoped to establish causation and to comment on prevention and treatment.

\section{Patients and methods}

An exhaustive Current Contents search was carried out for the period from 1 January 1990 to 31 December 2001 using

The Editors have satisfied themselves that all authors have contributed significantly to this publication the keywords '(radiofrequency, radio-frequency or radio frequency) and (liver or hepatic or hepatocellular)' without exclusion of any language. All abstract books from the same period published in Radiology, American fournal of Radiology, Fournal of Vascular and Interventional Radiology, European Radiology and Surgical Endoscopy were searched manually. Furthermore, relevant papers were identified from the reference lists of papers previously obtained through the search. Abstracts from recent international meetings were also analysed. Short reports were not excluded. The authors of one recent large study were contacted for more details concerning their abstract ${ }^{1}$.

In cases where the patient population of two or more reports overlapped, only the most detailed report was retained. Reports describing complications without specifying the size of the patient population were excluded from the calculation of global and specific complication rate, but were still included in the discussion of each type of 
complication. Common side-effects of RFC, such as pain, fever and nausea (the post-RFC syndrome, present in 87 per cent of patients ${ }^{2}$ ), as well as an asymptomatic right pleural effusion $^{3}$, were not regarded as complications.

\section{Results}

Eighty-two reports ${ }^{1,4-84}$ were included in the analysis. In total, 3670 patients were treated with percutaneous, laparoscopic or open RFC. The overall complication rate was 8.9 per cent (Table 1$)$. The mortality rate was 0.5 per cent (Table 2). The complication rate was similar for the percutaneous ( 7.2 per cent), laparoscopic ( 9.5 per cent) and simple open (9.9 per cent) approaches (Table 3). However, patients treated by open RFC combined with cryotherapy, hepatic or extrahepatic resection had a much higher morbidity rate ( 31.8 per cent). The mortality rate was 0.5 , 0,0 and 4.5 per cent respectively.

\section{Bleeding}

Clinically significant intraperitoneal bleeding after RFC occurred in 24 instances, one of which was fatal ${ }^{1}$. Bleeding was not limited to treatment of hepatocellular carcinoma (HCC) $)^{19,53,55,62,85}$, but occurred also in liver metastases ${ }^{18,73,74}$. It originated from an incompletely coagulated subcapsular tumour, from a bleeding electrode track, from a tear in the liver parenchyma ${ }^{53}$, from a hepatic rupture due to an intrahepatic haematoma ${ }^{10}$ or from delayed rupture of a hepatic artery pseudoaneurysm ${ }^{86}$. Treatment was mainly conservative; one embolization ${ }^{86}$ and four surgical interventions ${ }^{10,18,53,62}$ were described. Bleeding did not occur in any of 278 patients after cauterization of the electrode track, but occurred in ten ( 0.9 per cent) of 1154 patients who had no cauterization. It occurred in one $(0.3$ per cent) of 332 patients after open and laparoscopic procedures, and in 22 ( 0.8 per cent) of 2898 after percutaneous procedures. No bleeding was noted in 26 patients in whom the track was filled with gelatin sponge $e^{5,43}$.

\section{Intrahepatic and subcapsular haematoma}

A subcapsular haematoma (Fig. 1) was most often found after RFC of subcapsular tumours ${ }^{41,55}$. Intrahepatic (Fig. 1) and subcapsular haematoma occurred after treatment of both $\mathrm{HCC}^{20,55}$ and liver metastases ${ }^{30,41,47,74}$. Treatment of this complication was mainly conservative, with therapeutic embolization described in three patients ${ }^{20,25,41}$ and surgery in two ${ }^{10,81}$.

\section{Hepatic abscess}

Thirty-four hepatic abscesses (Fig. 2.), two of which were fatal $^{1,81}$, have been reported after RFC $\mathrm{RF}^{1,9,15,22,32,33,46,81,84}$. One abscess developed only after 5 months ${ }^{81,87}$. Treatment consisted of percutaneous drainage and intravenous antibiotics $^{33,81,84,88}$. At least eight patients who developed an abscess had an alteration of the biliary system: four had a biliary stent ${ }^{9,22}$, three a bilioenteric anastomosis ${ }^{22,33}$, and one a bile duct stricture ${ }^{81}$.

\section{Peritoneal infection}

One fatal case of Staphylococcus aureus peritonitis ${ }^{53}$ and one fatal case of infected ascites ${ }^{80}$ were reported. The former complication was attributed to a disruption of sterile technique.

\section{Biliary tract damage}

A biliary stricture was reported in 18 patients ${ }^{1,10,14,16,22,56 \text {, }}$ ${ }^{81,84}$, one of whom died ${ }^{1}$. Seven peripheral strictures ${ }^{14,16,22}$ were clinically asymptomatic. Central biliary strictures complicating RFC of hilar tumour ${ }^{16,56,81,84,89,90}$ cause cholestasis and require a stent ${ }^{56,81,84,89}$. Strictures may be complicated by an abscess ${ }^{81}$, a biliovenous fistula ${ }^{16}$, or lead to partial hepatic atrophy ${ }^{16}$. Strictures may become evident as late as 4 months after $\mathrm{RFC}^{56}$. There were seven biliomas $^{1,16,64,70}$ and six cases of bilioperitoneum ${ }^{10,22,32}$. Three of the bile leaks were attributed to a direct electrode injury of the main bile ducts ${ }^{10}$. Three reports of haemobilia were found ${ }^{30,53,84}$, one starting during $\mathrm{RFC}^{91}$ and another occurring 6 days after the procedure ${ }^{30}$. Other biliary tract damage included a biliocutaneous fistula ${ }^{5}$ and a fatal bile leak into the chest ${ }^{32}$. The rate of biliary complications was similar in patients treated by RFC without a Pringle manoeuvre (25 ( 0.8 per cent) of 3227$)^{1,5,10,14,22,30,32,53,70,81}$ and with a Pringle manoeuvre (one $(0.6$ per cent) of $159)^{26,34,37,46,56,59,92,93}$.

\section{Liver failure}

Seven instances of fatal liver failure were reported $^{1,10,15,22,64,81}$. Four were due to central vascular thrombosis ${ }^{1,22,64}$ and three to overestimation of liver reserve ${ }^{1,10,81}$. A transient mild deterioration of liver function was noted in 22 patients ${ }^{10,12,20,27,47,58,59,64,66}$. Child-Pugh grade increased by one to three points but returned to the preprocedural value within 2 weeks in most, but not all, patients. 
Table 1 Complications of radiofrequency coagulation in 3670 patients

\begin{tabular}{|c|c|c|}
\hline Complication & No. of patients & References \\
\hline Abdominal bleeding & $60(1 \cdot 6)$ & \\
\hline Intraperitoneal bleeding & $24(0.7)$ & $1,9,10,18,19,22,38,53,55,62,73,74$ \\
\hline Intrahepatic haematoma & $6(0.2)$ & $10,20,25,30,39$ \\
\hline Subcapsular haematoma & $20(0.5)$ & $5,9,20,22,32,41,47,55,74,81$ \\
\hline Abdominal wall bleeding & $1(0.0)$ & 20 \\
\hline Abdominal wall haematoma & $6(0.2)$ & $20,48,58$ \\
\hline Non-specified haematoma & $3(0.1)$ & 15,46 \\
\hline Abdominal infection & $42(1 \cdot 1)$ & \\
\hline Hepatic abscess & $34(0.9)$ & $1,9,15,22,32,33,46,81,84$ \\
\hline Wound infection & $4(0.1)$ & $10,56,64$ \\
\hline Peritoneal infection & $2(0.1)$ & 53,80 \\
\hline Unspecified sepsis & $2(0.1)$ & 1 \\
\hline Biliary tract damage & $38(1.0)$ & \\
\hline Biliary stricture & $18(0.5)$ & $1,10,14,16,22,56,81,84$ \\
\hline Bilioma & $7(0 \cdot 2)$ & $1,16,64,70$ \\
\hline Bilioperitoneum & $6(0.2)$ & 10, 22, 32 \\
\hline Haemobilia & $3(0.1)$ & $30,53,84$ \\
\hline Biliovenous fistula & $2(0.1)$ & 16 \\
\hline Biliocutaneous fistula & $1(0.0)$ & 5 \\
\hline Biliopleural fistula & $1(0 \cdot 0)$ & 32 \\
\hline Liver failure & $29(0 \cdot 8)$ & \\
\hline Fatal liver failure & $7(0.2)$ & $1,10,15,22,64,81$ \\
\hline Mild liver failure & $22(0.6)$ & $10,12,20,27,47,58,59,64,66$ \\
\hline Pulmonary & $29(0.8)$ & \\
\hline Pneumothorax & $10(0 \cdot 3)$ & $1,20,32,47,49,61$ \\
\hline Symptomatic pleural effusion & $7(0.2)$ & $20,22,53,74$ \\
\hline Haemothorax & $5(0.1)$ & $1,9,45,53$ \\
\hline Pneumonia & $5(0.1)$ & $22,46,64$ \\
\hline Pulmonary embolus & $1(0 \cdot 0)$ & 64 \\
\hline Adult respiratory distress syndrome & $1(0.0)$ & 15 \\
\hline Dispersive pad skin burn & $21(0.6)$ & $1,5,10,15,22,32,34,78$ \\
\hline Hepatic vascular damage & $22(0.6)$ & \\
\hline Portal vein thrombosis & $9(0.2)$ & $1,14,22,30,46,55,64$ \\
\hline Hepatic vein thrombosis & $2(0.1)$ & 16,32 \\
\hline Hepatic artery damage & $9(0.2)$ & $1,16,22,46,66$ \\
\hline Hepatic infarction, unspecified & $2(0.1)$ & 15,71 \\
\hline Visceral damage & $19(0.5)$ & \\
\hline Cholecystitis & $5(0.1)$ & $27,53,57,66$ \\
\hline Diaphragmatic burn & $5(0.1)$ & $1,25,32,54,81$ \\
\hline Colonic burn & $2(0.1)$ & 32,74 \\
\hline Gastric burn & $1(0.0)$ & 1 \\
\hline Jejunal burn & $1(0 \cdot 0)$ & 74 \\
\hline Renal burn & $2(0.1)$ & 1,54 \\
\hline Abdominal wall burn & $2(0.1)$ & 10,81 \\
\hline Non-specified damage & $1(0.0)$ & 46 \\
\hline Cardiac & $15(0.4)$ & \\
\hline Arrhythmia & $10(0.3)$ & $1,5,10,20,24,59,72,81$ \\
\hline Myocardial infarction & $2(0.1)$ & 5,81 \\
\hline Heart failure & $3(0.1)$ & 10,56 \\
\hline Myoglobinaemia and myoglobinuria & $8(0.2)$ & \\
\hline Myoglobinaemia & $3(0.1)$ & 70 \\
\hline Myoglobinuria & $5(0.1)$ & 10 \\
\hline Renal failure & $4(0.1)$ & $39,46,48,81$ \\
\hline Seeding & $7(0.2)$ & $24,25,55,74$ \\
\hline Coagulopathy & $6(0.2)$ & \\
\hline Thrombocytopenia & $5(0.1)$ & 10,56 \\
\hline Hypoprothrombinaemia & $1(0 \cdot 0)$ & 20 \\
\hline Hormonal & $4(0.1)$ & \\
\hline Carcinoid crisis & $2(0.1)$ & 33,81 \\
\hline Hyperglycaemia & $1(0.0)$ & 33 \\
\hline Addisonian crisis & $1(0.0)$ & 33 \\
\hline
\end{tabular}


Table 1 Continued

\begin{tabular}{lrl} 
Complication & No. of patients & References \\
\hline Miscellaneous & $9(0 \cdot 2)$ & 20,48 \\
Central hyperthermia & $2(0 \cdot 1)$ & 70 \\
Brachial plexopathy & $2(0 \cdot 1)$ & 55 \\
Oesophageal variceal bleeding & $1(0.0)$ & 72 \\
Gastrointestinal bleeding & $1(0.0)$ & 1 \\
Transient ischaemic attack & $1(0.0)$ & 69 \\
Difficult removal of electrode & $1(0.0)$ & 1 \\
Pseudoaneurysm of abdominal wall & $1(0.0)$ & 53,74 \\
Unspecified, minor & $14(0.4)$ &
\end{tabular}

Values in parentheses are percentages

Table 2 Mortality in 3670 patients undergoing radiofrequency coagulation

\begin{tabular}{lll} 
Cause of death & No. of patients & References \\
\hline Sepsis & $7(0 \cdot 2)$ & \\
$\quad$ Staphylococcus aureus peritonitis & 1 & 53 \\
Infected ascites & 1 & 80 \\
Biliopleural fistula & 1 & 32 \\
Hepatic abscess with diaphragmatic & 1 & 81 \\
$\quad$ necrosis & & \\
Hepatic abscess & 1 & 1 \\
S. aureus chest infection & 1 & 46 \\
Unspecified sepsis & 1 & 1 \\
Liver failure & $7(0 \cdot 2)$ & \\
Portal vein thrombosis & 3 & $1,22,64$ \\
Hepatic infarction & 1 & 15 \\
$\quad$ Extensive resection & 1 & 81 \\
Extensive coagulation & 1 & 10 \\
Advanced liver cirrhosis & 1 & 1 \\
Cardiac complications & $4(0.1)$ & \\
Carcinoid crisis & 2 & 33,81 \\
Cardiac arrest & 1 & 59 \\
$\quad$ Myocardial infarction & 1 & 5 \\
Peritoneal haemorrhage & $1(0.0)$ & 1 \\
Bile duct stricture & $1(0.0)$ & 1 \\
Total & $20(0.5)$ &
\end{tabular}

Values in parentheses are percentages

\section{Pulmonary complications}

Ten pneumothoraces were noted ${ }^{1,20,32,47,49,61}$, mostly after an intercostal percutaneous approach. Seven symptomatic pleural effusions occurred ${ }^{20,22,53,74}$. Five haemothoraces were due to damage of an intercostal vessel by the electrode $^{1,9,45,53}$. On ultrasonography, gas bubbles are frequently seen in the liver veins and in the right atrium, but pulmonary gas emboli have never been reported ${ }^{68,91}$. Five pneumonias ${ }^{22,46,64}$ were reported, one of which was fata ${ }^{46}$. Adult respiratory distress syndrome occurred only once $^{15}$.

\section{Dispersive pad skin burns}

Twenty-one instances of, mostly, first- and second-degree but also third-degree skin burns near or under the dispersive pad have been noted ${ }^{1,5,10,15,22,32,34,78}$ (Fig. 3). They occurred using Radiotherapeutics ${ }^{\circledR}$, (Sunnyvale, California, USA) ${ }^{5}$, RITA $^{\circledR}$ (RITA Medical Systems, Mountain View, California, USA) $)^{10,78}$ and Radionics ${ }^{\circledR}$ (Burlington, Massachusetts, USA) ${ }^{34,90,94,95}$ electrodes. In most reported burns, either high power (greater than $50 \mathrm{~W}$ ) had been used ${ }^{5,34,94,95}$, the procedure was long (more than $10 \mathrm{~min})^{34,94,95}$ or only one standard dispersive pad $\left(100 \mathrm{~cm}^{2}\right)^{34,90}$ had been placed. Several authors mentioned disappearance ${ }^{34,94}$ or decrease ${ }^{95}$ of the rate of skin burns after placing more or larger pads.

\section{Portal vein thrombosis}

Nine portal vein thromboses were reported ${ }^{1,14,22,30,46,55,64}$, three of which proved fatal ${ }^{1,22,64}$. Segmental portal thrombosis may remain asymptomatic ${ }^{86}$. Factors predisposing to portal vein damage are central location of the tumour close to the portal vein ${ }^{1,64,68}$, compression of the vein by the tumour ${ }^{96}$ and accidental puncture by the electrode. A higher rate of portal vein thrombosis occurred after a Pringle manoeuvre than when no such manoeuvre had been carried out. Of 3227 patients treated with RFC with normal liver blood flow, seven cases of portal vein thrombosis ${ }^{1,14,22,30,55}$ were described ( 0.2 per cent of cases). In 188 patients treated with RFC with a Pringle manoeuvre $^{26,34,37,46,56,59,64,68,92,93}$, four cases of portal vein thrombosis ${ }^{46,64,68}$ were reported (2.1 per cent of cases). A short (2-3 min) Pringle manoeuvre in the middle of the RFC procedure caused no thrombosis in a series of 92 patients $^{92}$, in contrast to four cases ( 4.2 per cent) in 96 patients when the manoeuvre was sustained throughout the whole RFC procedure $26,34,37,46,56,59,64,68,93$. 
Table 3 Complication rate of radiofrequency coagulation according to approach

\begin{tabular}{|c|c|c|c|c|}
\hline & $\begin{array}{l}\text { Percutaneous } \\
(n=2898)\end{array}$ & $\begin{array}{l}\text { Laparoscopic } \\
(n=168)\end{array}$ & $\begin{array}{l}\text { Simple open } \\
(n=142)\end{array}$ & $\begin{array}{l}\text { Combined open* } \\
(n=22)\end{array}$ \\
\hline Intraperitoneal bleeding & $22(0.8)$ & $1(0.6)$ & $0(0)$ & $0(0)$ \\
\hline Intrahepatic haematoma & $4(0.1)$ & $0(0)$ & $0(0)$ & $0(0)$ \\
\hline Subcapsular haematoma & $18(0.6)$ & $1(0.6)$ & $0(0)$ & $0(0)$ \\
\hline Abdominal wall bleeding or haematoma & $2(0.1)$ & $5(3.0)$ & $1(0.7)$ & $0(0)$ \\
\hline Abdominal infection & $31(1 \cdot 1)$ & $0(0)$ & $0(0)$ & $1(4.5)$ \\
\hline Biliary tract damage & $16(0.6)$ & $0(0)$ & $6(4 \cdot 2)$ & $1(4.5)$ \\
\hline Liver failure & $11(0.4)$ & $2(1 \cdot 2)$ & $3(2 \cdot 1)$ & $0(0)$ \\
\hline Pulmonary complications & $17(0.6)$ & $2(1 \cdot 2)$ & $0(0)$ & $1(4.5)$ \\
\hline Pad skin burn & $18(0.6)$ & $0(0)$ & $0(0)$ & $0(0)$ \\
\hline Hepatic vascular damage & $13(0.4)$ & $0(0)$ & $3(2 \cdot 1)$ & $1(4.5)$ \\
\hline Visceral damage & $14(0.5)$ & $0(0)$ & $0(0)$ & $0(0)$ \\
\hline Cardiac complications & $8(0.3)$ & $1(0.6)$ & $0(0)$ & $1(4.5)$ \\
\hline Myoglobinaemia and myoglobinuria & $3(0.1)$ & $1(0.6)$ & $0(0)$ & $0(0)$ \\
\hline Renal failure & $0(0)$ & $1(0.6)$ & $0(0)$ & $1(4.5)$ \\
\hline Seeding & $8(0.3)$ & $0(0)$ & $0(0)$ & $0(0)$ \\
\hline Coagulopathy & $0(0)$ & $0(0)$ & $0(0)$ & $1(4.5)$ \\
\hline Hormonal complications & $3(0.1)$ & $0(0)$ & $0(0)$ & $0(0)$ \\
\hline Miscellaneous & $6(0.2)$ & $2(1 \cdot 2)$ & $1(0.7)$ & $0(0)$ \\
\hline Unspecified, minor & $14(0.5)$ & $0(0)$ & $0(0)$ & $0(0)$ \\
\hline Total & $208(7.2)$ & $16(9.5)$ & $14(9.9)$ & $7(31 \cdot 8)$ \\
\hline Death & $14(0.5)$ & $0(0)$ & $0(0)$ & $1(4.5)$ \\
\hline
\end{tabular}

Only series detailing the total number of patients, the approach used, and the number and nature of all complications were included. Patients may have had more than one complication. *Open radiofrequency coagulation combined with cryotherapy, hepatic or extrahepatic resection

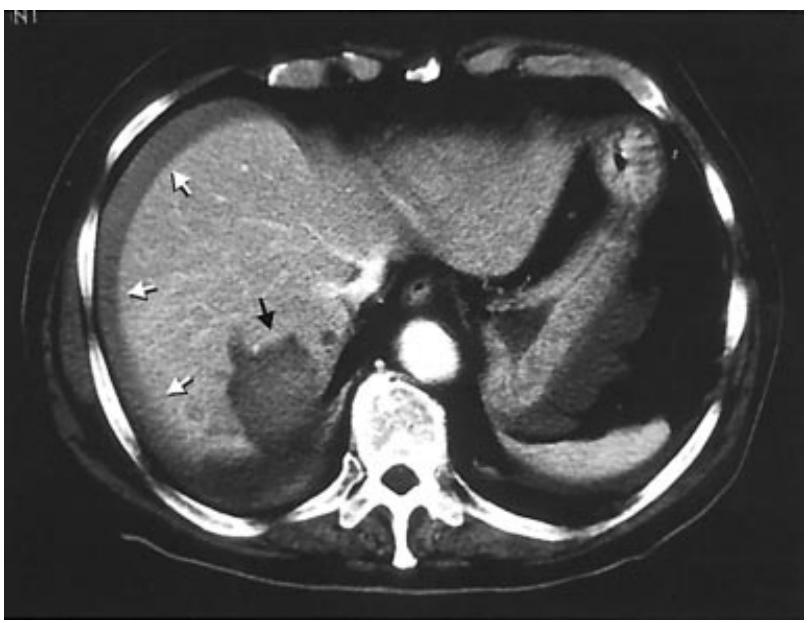

Fig. 1 Subcapsular haematoma (white arrows) and intrahepatic haematoma (black arrow) $24 \mathrm{~h}$ after percutaneous radiofrequency coagulation of a subcapsular colorectal metastasis in segment 7

\section{Hepatic vein thrombosis}

Only two instances of hepatic vein thrombosis causing peripheral infarction ${ }^{32}$ or collateral vein development ${ }^{16}$ have been observed.

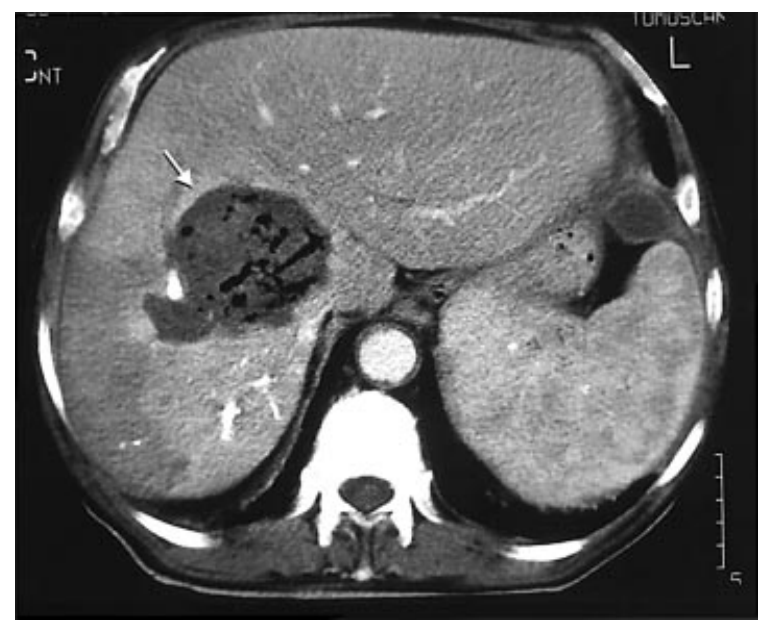

Fig. 2 Hepatic abscess (white arrow) 8 days after percutaneous radiofrequency coagulation of a hepatocellular carcinoma

\section{Hepatic artery damage}

Hepatic artery damage has been reported in nine patients ${ }^{1}$, $16,22,46,66$. One fatal and one non-fatal hepatic infarction ${ }^{1}$ due to simultaneous hepatic artery and portal vein 


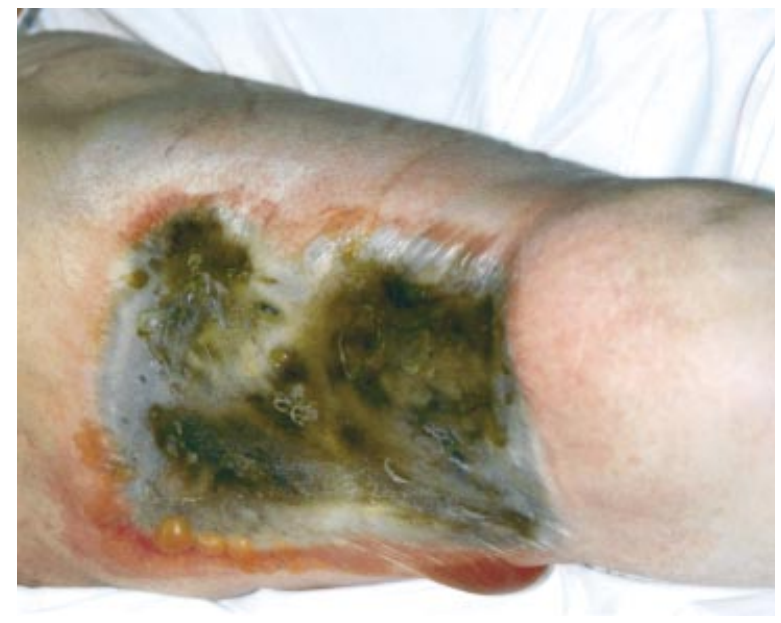

Fig. 3 Third-degree dispersive pad skin burn after a 2-h radiofrequency coagulation of a $10-\mathrm{cm}$ melanoma metastasis using a $200-W$ generator with only one $100-\mathrm{cm}^{2}$ dispersive pad

thrombosis occurred after RFC of a central tumour. Three important arterioportal shunts ${ }^{1,16}$ and two pseudoaneurysms ${ }^{16,22}$ were noted. One intimal dissection of the hepatic artery without clinical sequelae was observed after balloon catheter occlusion ${ }^{66}$.

\section{Visceral damage}

Visceral damage has occurred exclusively after percutaneous procedures. Five cases of post-RFC cholecystitis have been recognized ${ }^{27,53,57,66}$ after coagulation near the gallbladder. All were treated conservatively. Diaphragmatic injury has been described in five of the series of 3670 patients ${ }^{1,25,32,54,81}$, and in a further patient in another report $^{90}$ after RFC of a subdiaphragmatic tumour. Two burns were fatal as a result of bile leak into the chest ${ }^{32}$ or an associated abscess ${ }^{81}$. Two other burns caused pain lasting for 10 days to 3 months ${ }^{25,54}$. Another patient sustained a diaphragmatic paresis ${ }^{90}$. Two colonic burns have been reported, one resulting in perforation ${ }^{74}$ and one in fistula $^{32,95}$. One jejunal perforation required operation ${ }^{74}$, one gastric burn (Fig. 4) was due to RFC of a subcapsular tumour in the left lobe ${ }^{1}$, and two renal burns were caused by RFC of a subcapsular tumour in segments 6 and $7^{1,54}$. Two abdominal wall burns have been reported, one during track coagulation $^{81}$ and one without coagulation ${ }^{10}$.

\section{Cardiac complications}

Ten cases of rhythm disturbances were noted during or shortly after RFC: five vasovagal reactions or bradycar-

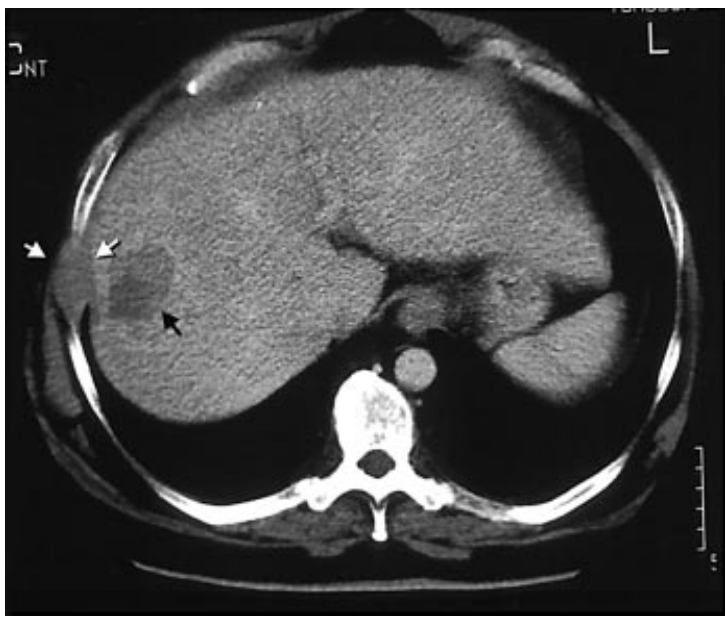

Fig. 4 Parietal wall seeding (white arrows) 1 year after direct percutaneous radiofrequency coagulation of a subcapsular hepatocellular carcinoma (black arrow). The electrode track had not been cauterized

$\operatorname{dias}^{1,5,24}$ (one of which required cardiac massage ${ }^{24}$ and another intravenous atropine ${ }^{5}$ ), one ventricular fibrillation treated by a single electrical discharge ${ }^{20}$, two arrhythmias after RFC of carcinoid metastases ${ }^{72,81}$, and one fatal cardiac arrest on day 20 after $\mathrm{RFC}^{59}$. Three patients with a pacemaker have undergone hepatic $\mathrm{RFC}^{10,97}$; malfunction was observed in one pacemaker ${ }^{10}$. Two instances of myocardial infarction were fatal; one was due to a carcinoid crisis $^{81}$ and the other was unrelated to the procedure ${ }^{5}$.

\section{Renal failure}

Four instances of renal failure have been recorded ${ }^{39,46,48,81}$. One involved a Staphylococcus aureus chest infection ${ }^{46}$, another a fatal carcinoid crisis $^{81}$, and a third was possibly caused by myoglobinuria ${ }^{48}$.

\section{Electrode track seeding}

Seven cases of electrode track seeding (Fig. 4) $24,25,55,74,98$ occurred in the series of 3670 patients, and a further three ${ }^{99-101}$ were reported outside this series. Other unpublished cases have been referred to ${ }^{102}$. They occurred after RFC of $\mathrm{HCC}^{24,55,98}$ and of colonic ${ }^{74,99,100}$, pancreatic $^{25}$ and carcinoid ${ }^{99,100}$ liver metastases. Seeding occurred after using monopolar ${ }^{99,100,103,104}$, RITA ${ }^{25,101}$ and Radionics $^{24,55,74,98,102}$ electrodes. In one series of RFC of single $\mathrm{HCCs}^{55}$, four instances of electrode track seeding after percutaneous RFC of a single HCCs in 32 patients were identified at 4, 6,7 and 18 months after treatment. All four tumours were subcapsular and two were poorly 
differentiated. No cauterization of the electrode track had been used in these patients for fear of burning the abdominal wall.

\section{Hormonal complications}

Among the 3670 patients treated with RFC, 77 had endocrine liver metastases $7,9,10,18,26,27,32,33,38,39,41,48,50,68,72,79,81$, 42 of which were carcinoid metastases ${ }^{10,18,26,27,33,38,48,68,72}$, 79,81 . In these 42 patients, two ( 4.8 per cent) fatal carcinoid crises occurred ${ }^{33,81}$, both after debulking of extensive disease with RFC with or without cryotherapy. In one of them, the crisis started only after $40 \mathrm{~h}^{33}$. One patient with an insulinoma became temporarily hyperglycaemic and one patient with a cortisol-secreting tumour had a transient addisonian crisis $^{33}$.

\section{Miscellaneous}

Two cases of hyperthermia have been reported after a lengthy (175-420 $\mathrm{min}$ ) RFC procedure; the core temperature rose to $38 \cdot 8-40 \cdot 2{ }^{\circ} \mathrm{C}^{20,48}$. Difficulty in removing a RITA radiofrequency electrode, because coagulated tissue had become caught between the hooks and the shaft, has been reported twice (Reference 69; F. Meloni, personal communication, 1998).

\section{Approach}

The complication rate was similar for the percutaneous (7.2 per cent), laparoscopic ( 9.5 per cent) and simple open (9.9 per cent) approaches (Table 3). Patients treated by open RFC combined with cryotherapy, hepatic or extrahepatic resection had a morbidity rate of 31.8 per cent. The mortality rate was $0.5,0,0$ and 4.5 per cent respectively. Of two patients treated by a thoracoscopic transdiaphragmatic approach $^{28,45}$, one developed pleural bleeding ${ }^{45}$.

\section{Discussion}

The worldwide reported complication and mortality rates (7.2 and 0.5 per cent respectively) for percutaneous RFC in this cumulative series is higher than the 1.5 and 0.1 per cent rates reported previously in an Italian study ${ }^{90}$, indicating that the complication risk of this rapidly spreading technique should not be underestimated. The true complication rate may be even higher than the rate calculated here, as some authors may have ignored minor complications. Furthermore, some late complications, such as bile duct strictures and electrode track seeding, may have been missed because of the short follow-up in many studies. Review of the available data has enabled the formulation of some recommendations on the prevention of complications and identification of risk factors.

\section{Prevention of complications}

\section{Intraperitoneal bleeding}

Cauterization of the electrode track $^{17,18,24,44,56,64,81,96,105-}$

${ }^{109}$ can be strongly recommended for all patients, to prevent both oozing and significant bleeding. Cauterization is achieved by continuing power during slow withdrawal of the electrode after stopping the cooling for cooled electrodes $^{64,109}$ and after retraction of the prongs for expandable electrodes ${ }^{68}$. Oozing from the hepatic electrode track is noted in $30-34$ per cent of patients ${ }^{58,92}$. Although oozing is most often limited to less than $7 \mathrm{ml} \mathrm{blood}^{92,109}$, it has been incriminated as promoting seeding of viable tumour cells ${ }^{55}$. It can be prevented completely by cauterization $^{109}$. Cauterization also effectively prevents post-RFC bleeding: no bleeding occurred in 214 patients having cauterization, compared with ten ( 1.0 per cent) of 1036 with no cauterization. While some apply cauterization only in cirrhotic liver ${ }^{7,109}$, the present authors advise it in all patients as both oozing ${ }^{109}$ and bleeding ${ }^{73,74}$ have been noted in non-cirrhotic liver.

The recommendation of track cauterization for all patients has two important implications. The first is that general anaesthesia is recommended for all procedures, as coagulation of the most superficial part of the track within $2-3 \mathrm{~cm}$ from the hepatic capsule is often painful for patients who are under conscious sedation ${ }^{55,110}$. The second is that a perpendicular percutaneous approach is not advised for RFC of subcapsular tumours, as correct track cauterization using this route will lead to burns of the abdominal wall and $\operatorname{skin}^{55,81}$.

In the authors' view, cauterization cannot be replaced by visual laparoscopic ${ }^{58,111}$ or open ${ }^{92}$ control of haemostasis. Coagulation of the point of entry of the electrode alone does not entirely prevent intraperitoneal bleeding, which occurred in one $(0.3$ per cent) of 332 patients after open and laparoscopic RFC, compared with 22 ( 0.8 per cent) of 2898 after percutaneous procedures. Furthermore, oozing is stopped rather than prevented, which is less ideal in the prevention of seeding. Experience with filling the electrode track with gelatin sponge $e^{5,43}$ is too limited to draw meaningful conclusions.

Because of the risk of bleeding, the authors agree with most other workers in the field who recommend a postprocedural monitoring of haemodynamic variables for at least 4- $6 \mathrm{~h}^{8,20,50,59,65,78,85,91,105,112-116}$, only two authors settling for less ${ }^{73,117}$. 


\section{Intrahepatic baematoma}

An intrahepatic haematoma may be caused by accidental transgression of a large blood vessel ${ }^{109}$. Prevention lies in carefully avoiding hepatic vessels on the way to the tumour. Inadvertent injury to blood vessels may be more likely with triple-cooled and expandable electrodes, as it is impossible to visualize all prongs at the same time ${ }^{118}$. Straight electrodes may be advisable for tumours in the vicinity of several blood vessels ${ }^{118}$.

\section{Hepatic abscess}

Bilioenteric anastomoses are known to increase the risk of septic complications after local treatment of liver tumours ${ }^{119}$ as a result of retrograde enteric bacterial contamination of the biliary tract in up to 90 per cent of patients ${ }^{120}$. Germs found in abscesses after RFC, chemoembolization or percutaneous ethanol injection (PEI) in patients with bilioenteric anastomoses included Escherichia coli, Clostridium perfringens, streptococcus D and enterococcus $^{88,119}$. Since the first description of abscesses after RFC, several groups ${ }^{88,121,122}$ have started to give prophylactic antibiotics, although scientific proof of their value is unavailable at this time. A logical choice of antibiotics is amoxycillin plus clavulanic acid, which is active against all these organisms. In high-risk patients (previous biliary tract manipulation), a duration of $48 \mathrm{~h}$ has been suggested; otherwise one preprocedural intravenous dose is given ${ }^{88}$.

Abscess after RFC is most likely when fever, leucocytosis and abundant intralesional gas are present ${ }^{16,123}$. Although the diagnosis is often obvious, several patients with an indolent course resulting in late diagnosis have been reported (malaise and a subfebrile state as the only symptoms) $)^{124}$. Intralesional gas is not synonymous with an abscess; gas bubbles in the coagulated area are seen in 63 per cent of computed tomography scans performed immediately after $\mathrm{RFC}^{116}$. At 1-month follow-up, however, gas should no longer be visible ${ }^{116}$. One abscess developed only after 5 months ${ }^{81,87}$, suggesting that the devitalized tumour served as a nidus for delayed infection.

\section{Peritoneal infection}

It is clear that RFC should be performed with a strictly aseptic technique in a custom-designed environment.

\section{Biliary tract damage}

Experimental data suggest that the large bile ducts are protected from thermal damage by the cooling effect of the portal vein and the hepatic artery that run along them ${ }^{124-}$

${ }^{126}$. With intact blood flow, only small bile ducts associated with thrombosed blood vessels with a diameter of less than $3 \mathrm{~mm}$ are destroyed ${ }^{125,126}$. Damage to the larger bile ducts (adjacent to blood vessels greater than $3 \mathrm{~mm}$ in diameter) has never been observed ${ }^{124,126}$. Main bile duct stenosis has been noted only after RFC during a Pringle manoeuvre ${ }^{124}$.

In clinical practice, however, intact blood flow does not decrease the risk of biliary complications. The fact that the number of reported biliary complications is limited is probably related to the warnings of this complication from the early days of $\mathrm{RFC}^{52,111}$. Most workers consider tumours closer than $1 \mathrm{~cm}$ to the main biliary ducts a contraindication to $\mathrm{RFC}^{3,4,12,20,29,93,107,110}$. However, two methods have recently been described to prevent biliary damage while treating central tumours ${ }^{26,81}$. One involved the prophylactic placement of a biliary stent in four patients having RFC of tumours near the major bile ducts; there were no complications ${ }^{81}$. The other involved the (successful) treatment of three central tumours while cooling the biliary ducts with chilled saline ${ }^{26}$. While these methods may decrease biliary damage, they may increase the risk of hepatic abscess formation. Prospective evaluation is needed.

\section{Dispersive pad skin burns}

As for electrocautery, the general recommendations for the placement of grounding pads ${ }^{127-130}$ must be observed. Specific extra precautions need to be taken for RFC. Using electrocautery, one standard pad is sufficient as the current is limited (700 mA or less) and intermittent. Using RFC, the risk of burns with one pad is much higher, as current can be as high as $2000 \mathrm{~mA}$ and is applied continuously for one or more session of 10-20 $\min ^{131}$.

An excellent experimental study ${ }^{131}$, using a $200-W$ generator for $10 \mathrm{~min}$, studied the variables that influenced heating under the pad. On the basis of this study, the use of four (rather than one) $100-\mathrm{cm}^{2}$ pads is recommended to increase the dispersive surface. The pads should be placed horizontally to allow a longer leading edge. They should be equidistant from the electrode to prevent excessive heating of the nearest pad. A distance to the electrode of at least $50 \mathrm{~cm}$ should be observed as pad temperature rises with shorter distances. In practice, for $200-\mathrm{W}$ generators the pads should be placed horizontally at the anterior and posterior aspect of the mid-thigh, $50 \mathrm{~cm}$ from the electrode ${ }^{131}$. This contrasts with earlier recommendations for low-power $(50 \mathrm{~W})$ generators ${ }^{66,107}$ that advocated pads to be placed on the back. The above study, although extremely useful, does not allow any conclusion on the safety of procedures exceeding $10 \mathrm{~min}$, or of serial procedures with short intervals. It is strongly recommended that manufacturers quickly develop a system of pad temperature monitoring with an automatic audible alarm and current shutdown. Meanwhile, temperature monitoring using thermistors sandwiched between the dispersive plate and the skin is advised ${ }^{7}$. 


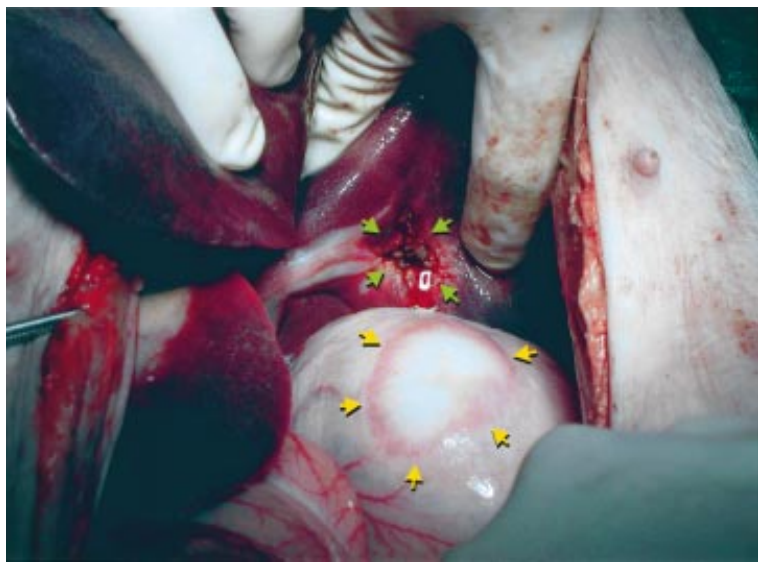

Fig. 5 Full-thickness stomach wall burn (yellow arrows) after a 12-min subcapsular radiofrequency coagulation (green arrows) at the undersurface of the left lobe of a pig liver without retracting the stomach

\section{Portal vein thrombosis}

In experimental studies, a Pringle manoeuvre enhances the risk of hepatic vessel thrombosis. After RFC with normal hepatic flow, vessels up to $3 \mathrm{~mm}$ show thrombosis ${ }^{125,132} ; 89$ per cent of vessels with a diameter of 3-4 mm and 100 per cent of those with a diameter greater than $4 \mathrm{~mm}$ remain patent $^{125,133-135}$. However, in experimental lesions produced with a Pringle manoeuvre, occlusive thrombosis has been observed even in large vessels (greater than $6 \mathrm{~mm})^{125,126}$. The absence of protection of the endothelium by the cooling blood flow during the manoeuvre translates clinically into a higher rate of thrombosis of nearby portal vein branches. The authors refrain from any Pringle manoeuvre in circumstances of portal vein compression by the tumour. The available data also discourage a full manoeuvre for tumours within $1 \mathrm{~cm}$ of the main portal vein branches $^{64,68}$. For such tumours a short (2-3 min) manoeuvre is an alternative that has until now never produced portal vein thrombosis ${ }^{92}$. A full Pringle manoeuvre for RFC of tumours at a distance from the main portal branches has, so far, never produced portal vein thrombosis.

Hepatic vein thrombosis, Budd-Chiari syndrome and inferior vena cava thrombosis

Hepatic vein thrombosis has been reported only twice ${ }^{16,32}$. Until now, no Budd-Chiari syndrome or inferior vena cava thrombosis has occurred after RFC, although both have been described after interstitial laser coagulation ${ }^{14,136}$. RFC of tumours in the fork between the inferior vena cava and one or more hepatic veins is probably safe, unless the veins are compressed by the tumour.

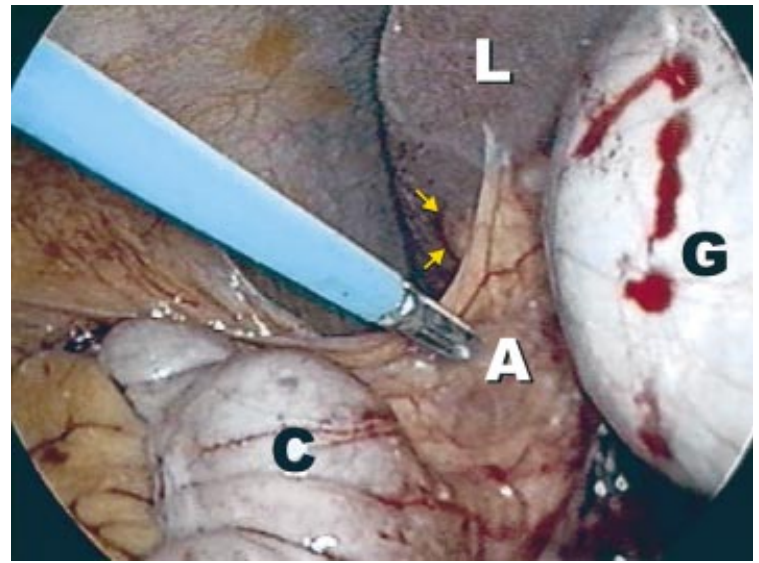

Fig. 6 The laparoscopic approach allows division of an adhesion between the transverse colon and a subcapsular segment 6 colorectal metastasis (yellow arrows) in order to avoid a colonic burn. A, adhesion; C, colon; G, gallbladder; L, liver

\section{Hepatic artery damage}

A small arterioportal shunt ${ }^{14,116,137}$ is found in 25 per cent of patients when carefully looked for at computed tomography immediately after $\mathrm{RFC}^{116}$. It is seen as a wedge-like high-attenuation lesion during the hepatic arterial phase. Eighty per cent of arterioportal shunts have disappeared at the 1-month follow-up; the remaining 20 per cent are no longer visible at 4-month follow-up ${ }^{116}$. The majority of arterioportal shunts heal spontaneously and need only simple follow-up. Only one massive shunt ${ }^{116}$ and one shunt associated with a growing pseudoaneurysm ${ }^{16}$ have been reported so far; such shunts should be embolized. Embolization of all pseudoaneurysms ${ }^{138}$ seems advisable, as they may experience delayed rupture with haemoperitoneum $^{86}$.

\section{Visceral damage}

A tumour closer than $1 \mathrm{~cm}$ to the gallbladder is a contraindication for a percutaneous procedure ${ }^{12,29,110,139}$. For tumours near the gallbladder, a laparoscopic or open approach allows cholecystectomy to avoid thermal cholecystitis or gallbladder perforation ${ }^{96,107}$. In contrast to other workers who remove the gallbladder before $\mathrm{RFC}^{107}$, the authors prefer to remove it after RFC to prevent spillage of tumour cells that are still viable ${ }^{96}$.

Burns of adjacent viscera have been predicted by a pig liver model, in which full-thickness burns of the stomach, small bowel and colon have been observed when the edge of the thermal lesion was less than $1 \mathrm{~cm}$ from the surface of the liver ${ }^{125,134,140}$ (Fig. 5). In the light of this an open or laparoscopic approach has been advocated for subcapsular tumours within $2 \mathrm{~cm}$ of adjacent viscera ${ }^{20,58,107,125,141}$. This 
way, these organs can be protected by separating them from the liver surface (Fig. 6). In the absence of adhesions between the viscus and the liver, peritoneal saline instillation creating artificial ascites is being studied as an alternative ${ }^{142}$.

\section{Cardiac complications}

The reports of rhythm disturbances stress the importance of continuous monitoring of vital signs and the presence of an anaesthetist during and for $1 \mathrm{~h}$ after the procedure, even if performed percutaneously $y^{3,20,34,143,144}$. Significant problems have been reported in patients undergoing RFC in a radiology suite without adequate anaesthesia ${ }^{20}$. Defibrillation devices should always be immediately available.

\section{Hypotension}

In experimental conditions, the combination of a pneumoperitoneum and clamping of the liver hilum may cause hypotension due to decreased venous return ${ }^{145}$. So far, this has not been reported in the clinical situation, but published experience with a Pringle manoeuvre during laparoscopic RFC is limited to four cases ${ }^{21,37}$.

\section{Acute renal failure}

Only one case of acute renal failure, which may have been caused by myoglobinaemia, has been reported after RFC that lasted for $7 \mathrm{~h}^{48}$. However, the frequency of myoglobinaemia or myoglobinuria after RFC is probably underestimated. When looked for routinely, myoglobinaemia was found in three of ten patients being treated for large or multiple tumours ${ }^{70}$. Similarly, myoglobinuria has been reported in none of $25^{146}$, and in five ( 6.6 per cent) of 76 patients ${ }^{10}$, and was associated with RFC of very large (up to $15 \mathrm{~cm}$ ) tumours ${ }^{10}$. In the near future, renal failure after RFC may become more frequent due to increasing coagulation diameter. More data are needed about the real prevalence and risk of myoglobinaemia. Until then, it is recommended that myoglobinaemia and myoglobinuria are measured routinely in situations of extensive coagulation to allow prompt recognition and preventive therapy (mannitol diuresis and alkalinization of the urine $)^{48}$. Furthermore, a staged procedure should be considered for extensive disease $^{48}$.

\section{Electrode track seeding}

The risk of electrode track seeding has been the subject of recent debate $24,55,98,102,147-150$ since one group noted this complication in 12.5 per cent of patients ${ }^{55}$. Most other workers report lower rates of seeding, from 0.2 per cent $^{90}$,
0.6 per cent ${ }^{149}$, to 2.8 per cent ${ }^{24}$. The reasons for these differences are not clear. It may be that the real incidence of seeding is underestimated in many series with a short follow-up, as it may be recognized as late as 18 months after the procedure ${ }^{55}$.

Several mechanisms may contribute to seeding. Viable tumour cells may adhere to a biopsy needle or to the electrode during its retraction. Tumour cells may also be carried into the track with a little bleeding. Furthermore, cells may be forced into the track by sudden intratumoral hyperpressure that is frequently encountered during RFC, audible as a popping sound. Finally, cells may be driven in when saline is injected into the tumour during or before $\mathrm{RFC}^{151}$. Incriminated risk factors for seeding are preprocedural biopsies ${ }^{152,153}$, poor differentiation of the tumour $^{55}$, no cauterization of the electrode track ${ }^{55}$, and a perpendicular approach to subcapsular tumours ${ }^{55}$. Some authors perform a preprocedural percutaneous ${ }^{20,37,65,66,85}$, $113,143,146$, laparoscopic ${ }^{7,111,121,154}$, or open ${ }^{56}$ fine-needle or core biopsy of the liver tumour. However, a 5 and 25 per cent risk of tumour seeding have been reported for HCC and colorectal liver metastases respectively ${ }^{152,153}$. It therefore appears that biopsy proof of the nature of the tumour before RFC should be avoided when the clinical picture (history, imaging and tumour markers) is sufficiently diagnostic ${ }^{3,85}$. Poor differentiation of the tumour is a known risk factor for seeding after fine-needle aspiration biopsy and $\mathrm{PEI}^{155}$, and is also associated with a higher risk of seeding after $\mathrm{RFC}^{55}$.

Oozing after retraction of the electrode, which occurs in 30 per cent of cases $^{92}$, may promote seeding of viable tumour cells ${ }^{55}$ and can be prevented completely by cauterization ${ }^{109}$. One group ${ }^{55}$ systematically cauterized the electrode track, except for subcapsular tumours for fear of abdominal wall burns; all four cases of seeding occurred in patients with subcapsular tumours. Although unproven, the authors feel strongly that cauterization should be performed not only at the end of each RFC procedure, but also before every repositioning of the electrode. The seeding risk seems to be greater for subcapsular tumours, especially when a direct, perpendicular approach is used ${ }^{148}$. Once Glisson's capsule is breached, the tumour can bleed and cells can leak out immediately ${ }^{102,156}$. Furthermore, correct cauterization in this approach would lead to burns of the abdominal wall and $\operatorname{skin}^{55,81}$. An indirect oblique approach, through a sufficient layer of non-tumoral tissue, first aiming at the hilar pole of the tumour, is advised ${ }^{148}$. In this way the tumour is devascularized before it is coagulated, Glisson's capsule is coagulated only at the end, and cauterization of the intrahepatic track can be performed safely ${ }^{24}$. No seeding occurred in a series of 63 patients in which direct puncture 
of subcapsular tumours was avoided ${ }^{148}$. While some groups at this time consider a subcapsular location to be a contraindication to RFC, especially for patients awaiting transplantation ${ }^{55,102,147}$, the present authors feel rather that a direct approach to these tumours is contraindicated. For subcapsular tumours, laparoscopy and laparotomy may often be the approach of choice, as they offer a greater degree of freedom for the indirect introduction of the electrode.

\section{Haematogenous seeding}

There is concern that RFC may increase the release of neoplastic cells into the circulation during the treatment, as has been observed after transarterial embolization ${ }^{157}$. In a recent study of 32 patients, tumour cells in peripheral blood were present in 34 per cent of patients just before RFC and in 44 per cent of patients $1 \mathrm{~h}$ after $\mathrm{RFC}^{55}$. No definite conclusion can be drawn because of small numbers. Furthermore, increased release of tumour cells in the bloodstream does not necessarily translate into increased haematogenous metastases.

\section{Coagulopathy}

A slight decrease in platelet count on the first day after RFC is common ${ }^{3,154}$. However, significant thrombopenia is rare after RFC, probably because there is no reperfusion, as in cryotherapy ${ }^{146}$. Platelet count less than $60000 \mu \mathrm{l}$ has been reported once after extensive RFC during $248 \mathrm{~min}^{56}$. The international normalized ratio usually shows little fluctuation in the postoperative period ${ }^{154}$.

\section{Hormonal complications}

A carcinoid crisis is an extremely dangerous complication after RFC of a carcinoid tumour due to haemodynamic instability and cardiac rhythm disturbances. Patients should be monitored in the intensive care unit for at least $48 \mathrm{~h}$ after such a procedure and receive a prophylactic octreotide infusion $^{48,158}$. Both recorded fatalities occurred after extensive procedures ${ }^{33,81}$; whether a staged approach for extensive disease is safer is not presently known.

\section{Risk factors for complications}

Complications after RFC for HCC are more common in Child-Pugh class C (27.6 per cent) than in class A ( 8.0 per cent) or class B ( 6.5 per cent $)^{20}$. RFC of subcapsular tumours carries a higher risk of intraperitoneal bleeding, subcapsular haematoma, seeding and visceral damage; RFC of central tumours predisposes to biliary tract and central vessel damage. Thermal damage to neighbouring organs is found exclusively in the percutaneous approach. The same is true for seeding, probably because of the impossibility of coagulating the electrode track for superficial tumours using the percutaneous approach ${ }^{55}$. The laparoscopic approach has a complication pattern similar to that of the percutaneous approach, while avoiding seeding and visceral damage. Complication and mortality rates of open RFC combined with resection were not significantly different from those of hepatic resection alone for colorectal metastases (19 and 2 per cent respectively) ${ }^{159}$. Extensive procedures for large or multiple tumours carry a higher risk of liver failure, dispersive pad skin burn, myoglobinaemia or myoglobinuria, thrombocytopenia and central hyperthermia. Staged treatment should be considered for these patients.

\section{Comparison with other interstitial techniques}

\section{Percutaneous ethanol injection}

Several trials have compared PEI and RFC in the treatment of small (3 cm or less) hepatocellular cancers. In a prospective non-randomized trial, no complications occurred after PEI in 44 patients, whereas five complications occurred after RFC in 42 patients $^{91}$. In a prospective randomized trial, no complications were observed after PEI in 50 patients or after RFC in $52^{51}$. In a comparative study that assessed seeding alone, seeding was observed after PEI in none of 100 patients, and in three of 28 patients after $\mathrm{RFC}^{98}$. This difference was attributed to the larger diameter (15-18 G) of radiofrequency electrodes compared with PEI needles, which increases bleeding during the procedure and so, in turn, seeding ${ }^{55}$.

\section{Cryotherapy}

In a retrospective study comparing cryotherapy $(n=130)$ and RFC $(n=14)$, the complication rates were 17 and 0 per cent, thrombocytopenia rates 90 versus 0 per cent, and mean blood loss was 800 versus $40 \mathrm{ml}$ respectively ${ }^{106}$. In a prospective non-randomized trial comparing intraoperative cryotherapy $(n=54)$ and RFC $(n=92)$, the complication rates were 41 and 3 per cent, and the mortality rates 2 and 0 per cent ${ }^{146}$. Brisk intraoperative haemorrhage from the cryoprobetrack that required packing was encountered in almost 80 per cent of those undergoing cryotherapy; there wasnoinstance of such haemorrhage after RFC. Intrahepatic abscess developed in 19 percent after cryotherapy; no abscess developed after RFC. Renal failure occurred in 4 per cent after cryotherapy and in 0 per cent after $\mathrm{RFC}^{146}$.

In contrast to cryotherapy, there is no reperfusion through injured blood vessels after RFC because vessels of up to $3 \mathrm{~mm}$ in diameter are coagulated along with the tumour ${ }^{125,132}$. There is therefore neither consumption of platelets nor activation of coagulation to cause a coagulopathy ${ }^{146,160}$. RFC probes are smaller than cryoprobes and 
their tracks can be coagulated during electrode withdrawal such that track bleeding is much less frequent ${ }^{146}$. Cracking of the parenchyma during thawing of the iceball, resulting in severe haemorrhage ${ }^{160}$, is not relevant to RFC. Furthermore, the instantaneous coagulation of proteins and the absence of reperfusion in RFC result in a diminished release of toxic factors ${ }^{161}$. This explains why renal failure due to myoglobinuria occurred in only one ( 0.03 per cent) of 3670 patients after RFC, compared with 1.4 per cent after cryotherapy ${ }^{162}$.

\section{Laser}

Complications after percutaneous interstitial laser therapy are similar to those after percutaneous RFC. In 676 patients, pleural effusion requiring drainage occurred in 2.2 per cent, subcapsular haematoma in 7.7 per cent, hepatic abscess in 0.9 per cent, peritoneal bleeding in 0.4 per cent, wound infection in 0.6 per cent, and bile duct injury in 0.3 per cent ${ }^{163}$. The mortality rate was 0.4 per cent. In a retrospective study comparing laser therapy $(n=36)$ and RFC $(n=38)$ for the percutaneous treatment of HCCs of up to $6 \mathrm{~cm}$ in diameter, no major complications were observed in either group ${ }^{164}$.

\section{Microwave}

In a prospective randomized study comparing microwave $(n=36)$ and RFC $(n=36)$, the respective complication rates were 11 and 3 per cent ${ }^{71}$.

\section{Conclusion}

The morbidity and mortality rates associated with RFC, while low, are higher than previously assumed. With adequate knowledge, many complications are preventable. It is conceivable that the complication rate may rise in the future when larger tumour volumes are coagulated by more powerful electrodes.

\section{Acknowledgements}

The authors thank Professor H. K. Lim for providing information additional to that in his abstract on complications of RFC in Korea ${ }^{1}$.

\section{References}

1 Lim HK, Nam G, Han S, Kim YH, Park CM, Kim P. Major complications after radiofrequency thermal ablation of hepatic tumors: a report of the Korean RF study group. Radiology 2001; 221(Suppl): 248.

2 Rhim H, Choi J, Kim Y, Koh BH, Cho OK, Seo HS. Radiofrequency thermal ablation of hepatic tumors: post- ablation syndrome. 7 Vasc Intervent Radiol 2000; 11(Suppl 2): 271-2.

3 Livraghi T, Goldberg SN, Lazzaroni S, Meloni F, Ierace T, Solbiati L et al. Hepatocellular carcinoma: radio-frequency ablation of medium and large lesions. Radiology 2000; 214: 761-8.

4 Allgaier HP, Deibert P, Zuber I, Olschewski M, Blum HE. Percutaneous radiofrequency interstitial thermal ablation of small hepatocellular carcinoma. Lancet 1999; 353: 1676-7.

5 Arata MA, Nisenbaum HL, Clark TWI, Soulen MC. Percutaneous radiofrequency ablation of liver tumors with the LeVeen probe: is roll-off predictive of response? $7 \mathrm{Vasc}$ Intervent Radiol 2001; 12: 455-8.

6 Bauer T, Spitz F, Nisenbaum H, Fraker D. Radiofrequency ablation therapy for large, complex hepatic metastases. 52nd Annual Meeting of the Society of Surgical Oncology. 1999 (Poster presentation).

7 Berber E, Flesher NL, Siperstein AE. Initial clinical evaluation of the RITA 5-centimeter radiofrequency thermal ablation catheter in the treatment of liver tumors. Cancer $\mathcal{F}$ 2000; 6(Suppl 4): S319-29.

8 Bezzi M, Rossi M, Marcelli G, Rossi P. Radiofrequency ablation of liver neoplasms. Eur Radiol 1999; 9: 783-4.

9 Blackman GE, Bettmann MA, Gemery JM, Langdon DR. Early experience with radiofrequency ablation of tumors of varying histology with follow-up. 7 Vasc Intervent Radiol 2000; 11(Suppl 2): 238.

10 Bowles BJ, Machi J, Limm WML, Severino R, Oishi AJ, Furumoto NL et al. Safety and efficacy of radiofrequency thermal ablation in advanced liver tumors. Arch Surg 2001; 136: 864-9.

11 Buscarini L, Rossi S, Fornari F, Di Stasi M, Buscarini E. Laparoscopic ablation of liver adenoma by radiofrequency electrocautery. Gastrointest Endosc 1995; 41: 68-70.

12 Buscarini L, Buscarini E, Di Stasi M, Quaretti P, Zangrandi A. Percutaneous radiofrequency thermal ablation combined with transcatheter arterial embolization in the treatment of large hepatocellular carcinoma. Ultraschall Med 1999; 20: 47-53.

13 Buscarini L, Buscarini E, Di Stasi M, Vallisa D, Quaretti P, Rocca A. Percutaneous radiofrequency ablation of small hepatocellular carcinoma: long-term results. Eur Radiol 2001; 11: 914-21.

14 Catalano O, Esposito M, Nunziata A, Siani A. Multiphase helical CT findings after percutaneous ablation procedures for hepatocellular carcinoma. Abdom Imaging 2000; 25: 607-14.

15 Chan R, Asch M, Kachura J, Ho CS, Greig P, Langer B. Radiofrequency ablation of malignant hepatic neoplasms. $\mathcal{F}$ Vasc Intervent Radiol 2001; 12(Suppl 1): S24.

16 Choi H, Loyer EM, DuBrow RA, Kaur H, David CL, Huang $\mathrm{S}$ et al. Radio frequency ablation of liver tumors: assessment of therapeutic response and complications. Radiographics 2001; 21(SI): 541-54.

17 Christians KK, Pitt HA, Rilling WS, Franco J, Quiroz FA, Adams MB et al. Hepatocellular carcinoma: multimodality management. Surgery 2001; 130: 554-9. 
18 Chung MH, Wood TF, Tsioulias GJ, Rose DM, Bilchik AJ. Laparoscopic radiofrequency ablation of unresectable hepatic malignancies. A phase 2 trial. Surg Endosc 2001; 15: $1020-6$.

19 Crucinio N, Palieri AP, Nacchiero MC, Cela EM, Muscatiello N, Sgarro C et al. Termoablazione mediante radiofrequenza: nuovo approccio nella terapia locoregionale dell'HCC. G Chir 2001; 22: 89-92.

20 Curley SA, Izzo F, Ellis LM, Nicolas Vauthey J, Vallone P. Radiofrequency ablation of hepatocellular cancer in 110 patients with cirrhosis. Ann Surg 2000; 232: 381-91.

21 Cuschieri A, Bracken J, Boni L. Initial experience with laparoscopic ultrasound-guided radiofrequency thermal ablation of hepatic tumours. Endoscopy 1999; 31: 318-21.

22 de Baere TJ, Smayra T, Kuoch V, Dromain C, Girish BV, Roche AJ et al. Complications of percutaneous radiofrequency ablation of liver tumors. Radiology 2001; 221(Suppl): P627.

23 De Santis M, Ariosi P, Romagnoli R. Combined percutaneous treatment with segmental embolization and radiofrequency thermal ablation of large liver tumors. Eur Radiol 2000; 10(Suppl 1): 298.

24 de Sio I, Castellano L, De Girolamo V, di Santolo SS, Marone A, Del Vecchio Blanco $\mathrm{C}$ et al. Tumor dissemination after radiofrequency ablation of hepatocellular carcinoma. Hepatology 2001; 34: 609-10.

25 Dodd GD III, Soulen MC, Kane RA, Livraghi T, Lees WR, Yamashita $\mathrm{Y}$ et al. Minimally invasive treatment of malignant hepatic tumors: at the threshold of a major breakthrough. Radiographics 2000; 20: 9-27.

26 Elias D, El Otmany A, Goharin A, Attalah D, De Baere T. How I do it: Intraductal cooling of the main bile ducts during intraoperative radiofrequency ablation. 7 Surg Oncol 2001; 76: 297-300.

27 Dupuy DE, Mayo-Smith WW, Cronan JJ. Radiofrequency ablation of large and multiple hepatic neoplasms. Radiology 2000; 214: 921-2 (Abstract).

28 Elias D, de Baere T, Goharin A, Lasser P, Roche A. Transpleurodiaphragmatic radiofrequency thermoablation of a liver metastasis. 7 Am Coll Surg 2000; 191: 683-5.

29 Francica G, Marone G. Ultrasound-guided percutaneous treatment of hepatocellular carcinoma by radiofrequency hyperthermia with a 'cooled-tip needle'. A preliminary clinical experience. Eur 7 Ultrasound 1999; 9: 145-53.

30 Francica G, Marone G, Solbiati L, D'Angelo V, Siani A. Hemobilia, intrahepatic hematoma and acute thrombosis with cavernomatous transformation of the portal vein after percutaneous thermoablation of a liver metastasis. Eur Radiol 2000; 10: 926-9.

31 Gervais DA, Goldberg SN, Arellano RS, Chung R, Mueller PR. Treatment of hepatocellular carcinoma in cirrhotic patients awaiting transplant: a new and evolving use of percutaneous radiofrequency ablation. Radiology 2000; 217(Suppl): 606-7 (Abstract).

32 Gillams A, Lees W. Radiofrequency ablation of liver tumours
- one year experience with the latest technology. Eur Radiol 2000; 10(Suppl): D22.

33 Gillams AR. Thermal ablation of liver metastases. Abdom Imaging 2001; 26: 361-8.

34 Goldberg SN, Gazelle GS, Compton CC, Mueller PR, Tanabe KK. Treatment of intrahepatic malignancy with radiofrequency ablation: radiologic-pathologic correlation. Cancer 2000; 88: 2452-63.

35 Goldstein RM, Orr DW, Meyer RL, Derrick HC, Westmoreland MV, Levy MF, Klintmalm GB. Treatment of hepatomas in cirrhotic patients with radiofrequency thermal ablation. Annual Meeting of the American Society of Transplant Surgeons. 2000.

36 Goletti O, Puglisi GA, Lippolis PV, Seccia M, Lorenzetti L, Lencioni $\mathrm{R}$ et al. Intraoperative radiofrequency thermal ablation: a new approach to the treatment of hepatic focal lesions. Surg Endosc 1998; 12: 590 (Abstract).

37 Goletti O, Lencioni R, Armillotta N, Puglisi A, Lippolis PV, Lorenzetti L et al. Laparoscopic radiofrequency thermal ablation of hepatocarcinoma: preliminary experience. Surg Laparosc Endosc Percutan Tech 2000; 10: 284-90.

38 Hänsler J, Becker D, Müller W, Neureiter D, Hahn EG. Perkutane Hochfrequenz-Thermotherapie (HFFT) mit perfundierten Nadelapplikatoren bei hepatozellulären Karzinomen und Lebermetastasen. Congress 'Ultraschall 1999'. Berlin: 1999 (Poster).

39 Hargreaves GM, Adam R, Bismuth H. Results after nonsurgical local treatment of primary liver malignancies. Langenbecks Arch Surg 2000; 385: 185-93.

40 Hein E, Rogalla P, Roiges M, Hamm B. Radiofrequency (RF) therapy of liver metastasis in renal cell carcinoma in combination with immunomodulatory therapy. Eur Radiol 2000; 10(Suppl): D41.

41 Helmberger T, Holzknecht N, Schopf U, Kulinna C, Rau H, Stabler A et al. Radiofrequenzablation von Lebermetastasen. Technik und erste Ergebnisse. Radiologe 2001; 41: 69-76.

42 Holtkamp W, Müller W. Sonographisch gesteuerte perkutane Hochfrequenzthermotherapie von Lebertumoren mit perfundierten Nadelelektroden. Z Gastroenterol 2000; 38: 221-7.

43 Horigome H, Nomura T, Nakao H, Fujino N, Murasaki G, Kanematsu $\mathrm{T}$ et al. Percutaneous radio-frequency ablation therapy using a clustered electrode for malignant liver tumors. 7 Clin Gastroenterol 2001; 32: 418-22.

44 Ikeda M, Okada S, Ueno H, Okusaka T, Kuriyama H. Radiofrequency ablation and percutaneous ethanol injection in patients with small hepatocellular carcinoma: a comparative study. 7pn 7 Clin Oncol 2001; 31: 322-6.

45 Ishikawa T, Kohno T, Shibayama T, Fukushima Y, Obi S, Teratani $\mathrm{T}$ et al. Thoracoscopic thermal ablation therapy for hepatocellular carcinoma located beneath the diaphragm. Endoscopy 2001; 33: 697-702.

46 Jiao LR, Hansen PD, Havlík R, Mitry RR, Pignatelli M, Habib N. Clinical short-term results of radiofrequency 
ablation in primary and secondary liver tumors. Am 7 Surg 1999; 177: 303-6.

47 Kainuma O, Asano T, Aoyama H, Takayama W, Nakagohri $\mathrm{T}$, Kenmochi $\mathrm{T}$ et al. Combined therapy with radiofrequency thermal ablation and intra-arterial infusion chemotherapy for hepatic metastases from colorectal cancer.

Hepatogastroenterology 1999; 46: 1071-7.

48 Keltner JR, Donegan E, Hynson JM, Shapiro WA. Acute renal failure after radiofrequency liver ablation of metastatic carcinoid tumor. Anesth Analg 2001; 93: 587-9.

49 Kidney DD, Yip G, Podnos YD, Imagawa DK.

Radiofrequency ablation of hepatocellular carcinoma by percutaneous image guidance versus laparoscopic technique. A comparative study. Eur Radiol 2001; 11: C16-17.

50 Lencioni R, Goletti O, Armillotta N, Paolicchi A, Moretti M, Ciono D et al. Radio-frequency thermal ablation of liver metastases with a cooled-tip electrode needle: results of a pilot clinical trial. Eur Radiol 1998; 8: 1205-11.

51 Lencioni R, Allgaier H-P, Cioni D, Olschewski M, Crocetti $\mathrm{L}$, Laubenberger J et al. A randomized comparison of percutaneous ethanol injection and radiofrequency thermal ablation for the treatment of small hepatocellular carcinoma. Eur Radiol 2001; 11(Suppl A): 172-3.

52 Livraghi T, Goldberg SN, Monti F, Bizzini A, Lazzaroni S, Meloni F et al. Saline-enhanced radio-frequency tissue ablation in the treatment of liver metastases. Radiology 1997; 202: 205-10.

53 Livraghi T, Meloni F, Gazelle GS, Goldberg SN, Lazzaroni $\mathrm{S}$, Solbiati L. Radiofrequency (RF) ablation in the treatment of hepatocellular carcinoma (HCC): experience in 259 patients. Radiology 1999; 213(P): 282-3 (Abstract).

54 Livraghi T, Goldberg SN, Solbiati L, Meloni F, Ierace T, Gazelle GS. Percutaneous radio frequency ablation of liver metastases from breast cancer: initial experience in 24 patients. Radiology 2001; 220: 145-9.

55 Llovet JM, Vilana R, Bru C, Bianchi L, Salmeron JM, Boix L et al. Increased risk of tumor seeding after percutaneous radiofrequency ablation for single hepatocellular carcinoma. Hepatology 2001; 33: 1124-9.

56 Machi J, Oishi AJ, Morioka WK, Yu M, Hundahl SA, Furumoto NL et al. Radiofrequency thermal ablation of synchronous metastatic liver tumors can be performed safely in conjunction with colorectal cancer resection. Cancer $\mathcal{F}$ 2000; 6(Suppl 4): S344-50.

57 Marone G, Francica G, Iodice G, D'Angelo V, Pastrore P, Albo $\mathrm{M}$ et al. Terapia loco-regionale del piccolo carcinoma epatocellulare con termoterapia percutanea ecoguidata. Argomenti Gastroenterol Clin 1996; 9: 225-30.

58 Montorsi M, Santambrogio R, Bianchi P, Opocher E, Zuin $\mathrm{M}$, Bertolini E et al. Radiofrequency interstitial thermal ablation of hepatocellular carcinoma in liver cirrhosis. Role of the laparoscopic approach. Surg Endosc 2001; 15: 141-5.

59 Nicoli N, Casaril A, Marchiori L, Mangiante G, Marini G, Colombari $\mathrm{R}$ et al. Intraoperative and percutaneous radiofrequency thermal ablation in the treatment of hepatocellular carcinoma. Chir Ital 2000; 52: 29-40.
60 Pereira PL, Trübenbach J, König CW, Viebahn R, Duda SH, Claussen CD. Phase II study: transarterial chemoembolization combined with single session radiofrequency ablation of liver carcinomas larger than $5 \mathrm{~cm}$. Radiology 2001; 221(Suppl): P250.

61 Podnos YD, Henry G, Ortiz JA, Ji P, Cooke J, Cao S et al. Laparoscopic ultrasound with radiofrequency ablation in cirrhotic patients with hepatocellular carcinoma: technique and technical considerations. Am Surg 2001; 67: 1181-4.

62 Poggi G, Gatti C, Baldi M. Complicanze della termoablazione percutanea con radiofrequenza delle lesioni primitive e secondarie del fegato. Descrizione di un caso. Radiol Med (Torino) 2000; 100: 185-7.

63 Pulvirenti A, Garbagnati F, Regalia E, Coppa J, Marchiano A, Romito R et al. Experience with radiofrequency ablation of small hepatocellular carcinomas before liver transplantation. Transplant Proc 2001; 33: 1516-17.

64 Risse O, Sengel C, Penillon S, Arvieux C, Voirin D, Letoublon C. Destruction de tumeurs hépatiques malignes par radiofréquence. Experience préliminaire a propos de 25 cas. Ann Chir 2001; 126: 118-26.

65 Rossi S, Di Stasi M, Buscarini E, Quaretti P, Garbagnati F, Squassante L et al. Percutaneous RF interstitial thermal ablation in the treatment of hepatic cancer. $A \mathcal{F R} A m \mathcal{F}$ Roentgenol 1996; 167: 759-68.

66 Rossi S, Garbagnati F, Lencioni R, Allgaier HP, Marchiano A, Fornari F et al. Percutaneous radio frequency thermal ablation of nonresectable hepatocellular carcinoma after occlusion of tumor blood supply. Radiology 2000; 217: 119-26.

67 Rossi M, Pepino D, Bezzi F, Venditti F, Giglio L, Rossi P. RF thermal ablation: mid-term results in the treatment of HCC. Eur Radiol 2001; 11: C32.

68 Scudamore CH, Lee SI, Patterson EJ, Buezkowski AK, July LV, Chung SW et al. Radiofrequency ablation followed by resection of malignant liver tumors. Am $\mathcal{F}$ Surg 1999; 177: 411-17.

69 Seki T, Tamai T, Nakagawa T, Inoue K. Percutaneous radiofrequency $(\mathrm{RF})$ ablation therapy for hepatocellular carcinoma: difficulty in removing the expandable RF needle electrode. AfR Am 7 Roentgenol 2000; 174: 264-5.

70 Shankar S, Van Sonnenberg E, Silverman SG, Tuncali K, Van Den Abbeele AD, Whang EE. Impact of treatment of large and multiple hepatic lesions by percutaneous RF. Radiology 2001; 221(Suppl): P626.

71 Shibata T, Maetani Y, Ametani F, Kubo T, Itoh K, Konishi J. Tumor ablation therapy for small hepatocellular carcinoma: comparison of radiofrequency ablation and percutaneous microwave coagulation therapy. Radiology 2001; 221(Suppl): P248-9.

72 Siperstein AE, Berber E. Cryoablation, percutaneous alcohol injection, and radiofrequency ablation for treatment of neuroendocrine liver metastases. World 7 Surg 2001; 25: 693-6.

73 Solbiati L, Ierace T, Goldberg SN, Sironi S, Livraghi T, Fiocca R et al. Percutaneous US-guided radiofrequency tissue ablation of liver metastases: treatment and follow-up in 16 patients. Radiology 1997; 202: 195-203. 
74 Solbiati L, Ierace T, Livraghi T, Meloni F, Goldberg SN, Gazelle GS. Outcome and long-term survival of patients with liver metastases from colorectal cancer treated with percutaneous cool-tip radiofrequency ablation. Radiology 2001; 221(Suppl): P625-6.

75 Soulen MC, Drooz AT, Winick AB. Liver tumor ablation with the LeVeen radiofrequency probe: initial human experience. 7 Vasc Intervent Radiol 1999; 10(Suppl 2): 210.

76 Trübenbach J, Pereira PL, Huppert PE, König CW, Schick $\mathrm{F}$, Claussen CD. MRI-guided radiofrequency ablation of hepatic neoplasms. Eur Radiol 2000; 10: C8-9.

77 Trübenbach J, König CW, Duda SH, Schick F, Huppert PE, Claussen CD et al. Perkutane Radiofrequenzablation hepatischer Neoplasien unter Verwendung von 'Cluster'Ablationssonden - Erste klinische Erfahrungen. Rofo Fortschr Geb Rontgenstr Neuen Bildgeb Verfahr 2000; 172: 905-10.

78 Uchida S, Machi J, Tateishi T, Oishi RH, Oishi AJ, Shirouzu $\mathrm{K}$. Radiofrequency thermal ablation of unresectable liver tumors under percutaneous, laparoscopic and open intraoperative ultrasound guidance. American College of Surgeons (ACS) 85th Clinical Congress. San Francisco, California: 1999.

79 Wessels FJ, Schell SR. Radiofrequency ablation treatment of refractory carcinoid hepatic metastases. 7 Surg Res 2001; 95: $8-12$.

80 Wood BJ, Gervais DA, Goldberg SN, Gazelle GS, Tanabe KK, Mueller PR. Radiofrequency ablation (RFA) of primary liver tumors (HCC) and metastases: 2-year follow-up with special attention to reoccurrence $v s$ size and location of lesion, complications, modality used, and logistics of setting up an ablation. Radiology 1999; 213(P): 213 (Abstract).

81 Wood TF, Rose DM, Chung M, Allegra DP, Foshag LJ, Bilchik AJ. Radiofrequency ablation of 231 unresectable hepatic tumors: indications, limitations, and complications. Ann Surg Oncol 2000; 7: 593-600.

82 Yamakado K, Nakatsuka A, Horikiri N, Shiraki K, Ikoma J, Takeda K. Hepatocellular carcinoma: radio-frequency ablation combined with chemoembolization in small, medium, and large lesions. Radiology 2001; 221(Suppl): P249-50.

83 Yamasaki T, Kurokawa F, Shirahashi H, Kusano N, Hironaka K, Okita K. Percutaneous radiofrequency ablation therapy with combined angiography and computed tomography assistance for patients with hepatocellular carcinoma. Cancer 2001; 91: 1342-8.

84 Zoetmulder F, van Coevorden F. Radiofrequency of liver tumours. Focal liver pathology: diagnosis and therapy. Amsterdam: Netherlands Cancer Institute, 2000.

85 Choi D, Lim HK, Kim SH, Lee WJ, Jang HJ, Lee JY et al. Hepatocellular carcinoma treated with percutaneous radio-frequency ablation: usefulness of power Doppler US with a microbubble contrast agent in evaluating therapeutic response. Preliminary results. Radiology 2000; 217: 558-63.

86 Torres E, Benito A, Cano D, Larrache J, Bergaz F, Bilbao JI. Vascular complications after hepatic tumor radiofrequency. Eur Radiol 2001; 11(Suppl A): 410.
87 Bilchik AJ, Rose DM, Allegra DP, Bostick PJ, Hsueh E, Morton DL. Radiofrequency ablation: a minimally invasive technique with multiple applications. Cancer 7 Sci Am 1999; 5: 356-61.

88 de Baere T. Radiofrequency ablation of hepatic tumors. Second European Conference: Perspectives in Colorectal Cancer. Barcelona: 2000; 37-8.

89 Havlik R. Radiofrequency thermal ablation in liver tumours. Annual Course in Hepatobiliary and Pancreatic Surgery, Hammersmith Hospital. London: 1999.

90 Livraghi T, Solbiati L, Meloni F, Ierace T, Goldberg SN. Complications after cool-tip RF ablation of liver cancer: initial report of the Italian Multicenter Cooled-tip RF Study Group. Radiology 2000; 217(Suppl): P27 (Abstract).

91 Livraghi T, Goldberg SN, Lazzaroni S, Meloni F, Solbiati L, Gazelle GS. Small hepatocellular carcinoma: treatment with radio-frequency ablation versus ethanol injection. Radiology 1999; 210: 655-61.

92 Curley SA, Izzo F, Delrio P, Ellis LM, Granchi J, Vallone P et al. Radiofrequency ablation of unresectable primary and metastatic hepatic malignancies: results in 123 patients. Ann Surg 1999; 230: 1-8.

93 Elias D, Goharin A, El Otmany A, Taieb J, Duvillard P, Lasser $\mathrm{P}$ et al. Usefulness of intraoperative radiofrequency thermoablation of liver tumours associated or not with hepatectomy. Eur 7 Surg Oncol 2000; 26: 763-9.

94 De Baere T, Elias D, Ducreux M, Dromain C, Kuoch V, Gamal El Din M et al. Ablathermie percutanée des métastases hépatiques par radiofréquence. Expérience préliminaire. Gastroenterol Clin Biol 1999; 23: 1128-33.

95 Gillams AR, Lees WR, Ledermann JR, Taylor I. Experience with the triple cluster, cooled-tip radiofrequency electrodes in 76 liver tumours. Radiology 1999; 213(P): 124 (Abstract).

96 Mulier S, Mulier P, Miao Y, Ni Y, Marchal G, Van Steenbergen $W$ et al. Radiofrequentie-ablatie van tumoren: een overzicht. Tijdschr Geneesk 2001; 57: 51-61.

97 Hayes DL, Charboneau JW, Lewis BD, Asirvatham SJ, Dupuy DE, Lexvold NY. Radiofrequency treatment of hepatic neoplasms in patients with permanent pacemakers. Mayo Clin Proc 2001; 76: 950-2.

98 Llovet JM, Vilana R, Brù C, Bianchi L, Salmeron JM, Sala M et al. Increased risk of tumor seeding after radiofrequency thermal ablation for single hepatocellular carcinoma. Hepatology 2000; 32: 206A.

99 Mazziotti A, Cavallari A. Percutaneous US-guided ablation of liver metastases. Radiology 1997; 205: 582-4.

100 Mazziotti A, Grazi GL, Gardini A, Cescon M, Pierangeli F, Ercolani G et al. An appraisal of percutaneous treatment of liver metastases. Liver Transpl Surg 1998; 4: 271-5.

101 McGahan JP, Dodd GD III. Radiofrequency ablation of the liver: current status. AfR Am 7 Roentgenol 2001; 176: $3-16$.

102 Llovet JM, Vilana R, Bru C, Bianchi L, Bruix J. Tumor dissemination after radiofrequency ablation of hepatocellular carcinoma. Reply. Hepatology 2001; 34: 610-11.

103 Solbiati L, Goldberg SN, Livraghi T, Gazelle GS. 
Percutaneous US-guided radiofrequency tissue ablation of liver metastases. Reply. Radiology 1997; 205: 583-4.

104 Buscarini L, Buscarini E. Percutaneous ultrasound-guided radiofrequency ablation of liver tumors. Liver Transpl Surg 1999; 5: 255-7.

105 Rhim H, Dodd GD III. Radiofrequency thermal ablation of liver tumors. 7 Clin Ultrasound 1999; 27: 221-9.

106 Bilchik AJ, Wood TF, Allegra D, Tsoulias GJ, Chung M, Rose DM et al. Cryosurgical ablation and radiofrequency ablation for unresectable hepatic malignant neoplasms: a proposed algorithm. Arch Surg 2000; 135: 657-64.

107 Siperstein A, Garland A, Engle K, Rogers S, Berber E, String A et al. Laparoscopic radiofrequency ablation of primary and metastatic liver tumors. Technical considerations. Surg Endosc 2000; 14: 400-5.

108 Dodd GD. Radiofrequency thermal ablation of hepatic tumors. 7 Vasc Intervent Radiol 2000; 11(Suppl 2): 118-19.

109 de Baere T, Denys A, Johns Wood B, Lassau N, Kardache M, Vilgrain $\mathrm{V}$ et al. Radiofrequency liver ablation: experimental comparative study of water-cooled versus expandable systems. AfR Am 7 Roentgenol 2001; 176: 187-92.

110 Solbiati L, Ierace T, Goldberg SN, Dellanoce M, Cova L, Gazelle GS. Radiofrequency thermal ablation of liver metastases. In: Bartolozzi C, Lencioni R, eds. Liver Malignancies. Diagnostic and Interventional Radiology. Berlin: Springer, 1999: 339-53.

111 Siperstein AE, Rogers SJ, Hansen PD, Gitomirsky A. Laparoscopic thermal ablation of hepatic neuroendocrine tumor metastases. Surgery 1997; 122: 1147-55.

112 Sabo B, Dodd GD, Halff GA, Naples JJ. Anesthetic considerations in patients undergoing percutaneous radiofrequency interstitial tissue ablation. AANA F 1999; 67: 467-8.

113 Rossi S, Buscarini E, Gabargnati R, Di Stasi M, Quaretti P, Rago M et al. Percutaneous treatment of small hepatic tumors by an expandable RF needle electrode. A7R Am 7 Roentgenol 1998; 170: 1015-22.

114 Sironi S, Livraghi T, Meloni F, De Cobelli F, Ferrero CG, Del Maschio A. Small hepatocellular carcinoma treated with percutaneous RF ablation: MR imaging follow-up. AfR Am $\mathcal{F}$ Roentgenol 1999; 173: 1225-9.

115 Marone G, Francica G, D'Angelo V, Iodice G, Pastore P, Altamura $\mathrm{G}$ et al. Ablazione percutanea ecoguidata del carcinoma epatocellulare su cirrosi mediante radiofrequenza con 'ago freddo'. Radiol Med (Torino) 1998; 95: 624-9.

116 Lim HK, Choi D, Lee WJ, Kim SH, Lee SJ, Jang HJ et al. Hepatocellular carcinoma treated with percutaneous radiofrequency ablation: evaluation with follow-up multiphase helical CT. Radiology 2001; 221: 447-54.

117 Crespi G, Ruffa D, Farioli S, Centemeri MD, Servadio G, Foglia E et al. Neurolepatoanalgesia in patienti sottoposti a radiofrequenza percutanea ecoguidata per neoplasie epatiche primitive o secondarie, singole o multiple. Minerva Anestesiol 1998; 64: 267-70.

118 Rhim H, Goldberg SN, Dodd GD III, Solbiati L, Lim HK, Tonolini M et al. Essential techniques for successful radio- frequency thermal ablation of malignant hepatic tumors. Radiographics 2001; 21(SI): 517-35.

119 de Baere T, Roche A, Amenabar JM, Legrange C, Ducreux M, Rougier $\mathrm{P}$ et al. Liver abscess formation after local treatment of liver tumors. Hepatology 1996; 23: 1436-40.

120 Spies JB, Rosen RJ, Lebowitz AS. Antibiotic prophylaxis in vascular and interventional radiology: a rational approach. Radiology 1988; 166: 381-7.

121 Berber E, Foroutani A, Garland A, Rogers SJ, Engle KL, Ryan TL et al. Use of CT Hounsfield unit density to identify ablated tumor after laparoscopic radiofrequency ablation of hepatic tumors. Surg Endosc 2000; 14: 799-804.

122 Solbiati L, Ierace T, Tonolini M, Osti V, Cova L. Radiofrequency thermal ablation of hepatic metastases. Eur $\mathcal{F}$ Ultrasound 2001; 13: 149-58.

123 Catalano O, Nunziata A, Esposito M, Sandomenico F, Siani A. Helical CT patterns of recurrence after percutaneous ablation therapy for hepatocellular carcinoma (HCC). Eur Radiol 2000; 10(Suppl): D44.

124 de Baere T, Elias D, Dromain C, Din MG, Kuoch V, Ducreux $\mathrm{M}$ et al. Radiofrequency ablation of 100 hepatic metastases with a mean follow-up of more than 1 year. $A 7 R A m \mathcal{F}$ Roentgenol 2000; 175: 1619-25.

125 Hansen PD, Rogers S, Corless CL, Swanstrom LL, Siperstein AE. Radiofrequency ablation lesions in a pig liver model. $\mathcal{F}$ Surg Res 1999; 87: 114-21.

126 Patterson EJ, Scudamore CH, Owen DA, Nagy AG, Buczkowski AK. Radiofrequency ablation of porcine liver in vivo: effects of blood flow and treatment time on lesion size. Ann Surg 1998; 227: 559-65.

127 Emergency Care Research Institute. Skin injury in the OR and elsewhere. Health Devices 1980; 9: 312-18.

128 Gendron F. 'Burns' occurring during lengthy surgical procedures. 7 Clin Eng 1980; 51: 19-26.

129 Becker CM, Malhotra IV, Hedley-Whyte J. The distribution of radiofrequency current and burns. Anesthesiology 1973; 38: $106-22$

130 Allen JW, Geddes LA, Pearce JA, Mullikin JC. The effect of adipose tissue on the thermal performance of electrosurgical dispersive electrodes. 7 Clin Eng 1981; 6: 313-17.

131 Goldberg SN, Solbiati L, Halpern EF, Gazelle GS. Variables affecting proper system grounding for radiofrequency ablation in an animal model. 7 Vasc Intervent Radiol 2000; 11: 1069-75.

132 Hänsler JM, Becker D, Müller W, Neureiter D, Hahn EG. Sonographisch gesteuerete interstitielle Hochfrequenzthermotherapie (HFTT) - Untersuchungen am Modell des Hausschweins. Ultraschall Med 1998; 19(Suppl I): $103 \mathrm{~A}$.

133 Lu DS, Wang MP, Vodopich DJ, Raman SS. The effect of vessels on hepatic RF lesion creation: assessment of the 'heat sink effect'. Radiology 2000; 217(Suppl): P-229 (Abstract).

134 Buczkowski AK, Scudamore CH, Patterson EJ, Nagy AG, Owen DA. Safety study of hepatic radiofrequency ablation in an animal model. 13th Annual Meeting of the Academy of Surgical Research. San Antonio, Texas: 1997. 
135 Hänsler J, Becker D, Müller W, Neureiter D, Hahn EG. Perkutaneous Radio-frequency liver tissue ablation (RFTA) examinations on a pig model. 8th International Congress on Interventional Ultrasound. Herlev, Denmark: 1999 (Abstract 74).

136 Heisterkamp J, van Hilligersberg R, IJzermans JNM. Interstitial laser coagulation for hepatic tumours. Br 7 Surg 1999; 86: 293-304.

137 Lencioni R, Cioni D, Bartolozzi C. Percutaneous radiofrequency thermal ablation of liver malignancies: techniques, indications, imaging findings, and clinical results. Abdom Imaging 2001; 26: 345-60.

138 Bilchik AJ, Wood TF, Allegra DP. Radiofrequency ablation of unresectable hepatic malignancies: lessons learned. Oncologist 2001; 6: 24-33.

139 Lewin JS, Connell CF, Duerk JL, Chung YC, Clampitt ME, Spisak J et al. Interactive MRI-guided radiofrequency interstitial thermal ablation of abdominal tumors: clinical trial for evaluation of safety and feasibility. 7 Magn Reson Imaging 1998; 8: 40-7.

140 Scudamore C, Buczkowski A, Nagy A, Patterson E. Possible injuries to intrahepatic and perihepatic structures with radiofrequency probe. Surg Endosc 1997; 11: 193 (Abstract).

141 Dupuy DE, Goldberg SN. Image-guided radiofrequency tumor ablation: challenges and opportunities. Part II. 7 Vasc Intervent Radiol 2001; 12: 1135-48.

142 Ohmoto K, Yamamoto, S. Percutaneous microwave coagulation therapy using artificial ascitis. $A \mathcal{F} A m \mathcal{F}$ Roentgenol 2001; 176: 817-18.

143 Solbiati L, Goldberg SN, Ierace T, Dellanoce M, Livraghi T, Gazelle GS. Radio-frequency ablation of hepatic metastases: postprocedural assessment with a US microbubble contrast agent - early experience. Radiology 1999; 211: 643-9.

144 Goldberg SN, Gazelle GS, Mueller PR. Thermal ablation therapy for focal malignancy: a unified approach to underlying principles, techniques, and diagnostic imaging guidance. A7R Am 7 Roentgenol 2000; 174: 323-31.

145 Haberstroh J, Ahrens M, Munzar T, Waninger J, Salm R, Matern U et al. Effects of the Pringle maneuver on hemodynamics during laparoscopic liver resection in the pig. Eur Surg Res 1996; 28: 8-13.

146 Pearson AS, Izzo F, Fleming RYD, Ellis LM, Delrio P, Roh MS et al. Intraoperative radiofrequency ablation or cryoablation for hepatic malignancies. Am $\mathcal{F}$ Surg 1999; 178: 592-9.

147 Kato T, Reddy KR. Radiofrequency ablation for hepatocellular carcinoma: help or hazard? Hepatology 2001; 33: $1336-7$.

148 Bolondi L, Gaiani S, Celli N, Piscaglia F. Tumor dissemination after radiofrequency ablation of hepatocellular carcinoma. Hepatology 2001; 34: 608.

149 Livraghi T. Tumor dissemination after radiofrequency ablation of hepatocellular carcinoma. Hepatology 2001; 34: 608-9.

150 Goldberg SN, Solbiati L. Tumor dissemination after radiofrequency ablation of hepatocellular carcinoma. Hepatology 2001; 34: 609.

151 Miao Y, Ni Y, Mulier S, Wang K, Hoey MF, Mulier P et al. Ex vivo experiment on radiofrequency liver ablation with saline infusion through a screw-tip cannulated electrode. 7 Surg Res 1997; 71: 19-24.

152 Takamori R, Wong LL, Dang C, Wong L. Needle-track implantation from hepatocellular cancer: is needle biopsy of the liver always necessary? Liver Transpl 2000; 6: 67-72.

153 Plant GR, John TG, Ress M. Tumour seeding - an inevitable, or avoidable, legacy of biopsy of colorectal liver metastases? $\mathcal{F}$ Vasc Intervent Radiol 2000; 11(Suppl 2): 207.

154 Siperstein A, Garland A, Engle K, Rogers S, Berber E, Foroutani A et al. Local recurrence after laparoscopic radiofrequency thermal ablation of hepatic tumors. Ann Surg Oncol 2000; 7: 106-13.

155 Di Stasi M, Buscarini L, Livraghi T, Giorgio A, Salmi A, De Sio I et al. Percutaneous ethanol injection in the treatment of hepatocellular carcinoma. A multicenter survey of evaluation practices and complication rates. Scand 7 Gastroenterol 1997; 32: 1168-73.

156 Buscarini L, Fornari F, Bolondi L, Colombo P, Livraghi T, Magnolfi $\mathrm{F}$ et al. Ultrasound guided fine-needle biopsy of focal liver lesions: techniques, diagnostic accuracy and complications. A retrospective study on 2091 biopsies. $\mathcal{F}$ Hepatol 1990; 11: 344-8.

157 Boix L, Bruix J, Castells A, Vianney A, Llovet JM, Rivera F et al. Circulating mRNA for alpha-fetoprotein in patients with hepatocellular carcinoma. Evidence of tumor dissemination after transarterial embolisation. Hepatology 1996; 24: 349 (Abstract).

158 Gillams AR, Lees WR. Radiofrequency ablation of neuroendocrine liver metastases. Radiology 2001; 221(Suppl): P627.

159 Buell JF, Rosen S, Yoshida A, Labow D, Limsrichamrern S, Cronin DC et al. Hepatic resection: effective treatment for primary and secondary tumors. Surgery 2000; 128: 686-93.

160 Sarantou T, Bilchik A, Ramming KP. Complications of hepatic cryosurgery. Semin Surg Oncol 1998; 14: 156-62.

161 Chapman WC, Debelak JP, Wright Pinson C, Washington MK, Atkinson JB, Venkatakrishnan A et al. Hepatic cryoablation, but not radiofrequency ablation, results in lung inflammation. Ann Surg 2000; 231: 752-61.

162 Seifert JK, Junginger T, Morris DL. A collective review of the world literature on hepatic cryotherapy. $7 R$ Coll Surg Edinb 1998; 43: 141-54.

163 Vogl TJ, Eichler K, Straub R, Engelmann K, Zangos S, Woitaschek D et al. Laser-induced thermotherapy of malignant liver tumors: general principles, equipment(s), procedure(s) - side effects, complications and results. Eur 7 Ultrasound 2001; 13: 117-27.

164 Rossi M, Pacella CM, Bezzi M, Pepino D, Perleoni M, Rossi P. RF $v s$ laser thermal ablation in the treatment of HCC. Radiology 2000; 217(Suppl): 538 (Abstract). 


\section{Current address of Stefaan Mulier :}

Stefaan Mulier, MD

Philipslaan 66

3000 Leuven

Belgium

+3216356786

+32 498787357

stefaan.mulier@skynet.be

http://drmulier.com/research.html 